HUNGARIAN AGRICULTURAL ENGINEERING

$N^{\circ} 28 / 2015$ 39-43

Published online: http://hae-journals.org/

HU ISSN 0864-7410 (Print) / HU ISSN 2415-9751(Online)

DOI: 10.17676/HAE.2015.28.39
PERIODICAL OF THE COMITTEE OF AGRICULTURAL AND BIOSYSTEM ENGINEERING OF

THE HUNGARIAN ACADEMY OF SCIENCES and

SZENT ISTVÁN UNIVERSITY

Faculty of Mechanical Engineering

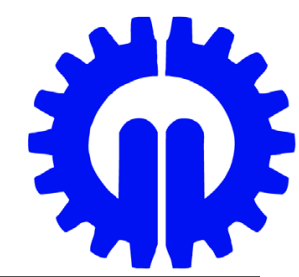

\title{
TEMPORAL AND SPATIAL VARIATIONS OF GROUNDWATER LEVEL AND SALINITY: A CASE STUDY IN THE IRRIGATED AREA OF MENEMEN PLAIN IN WESTERN TURKEY
}

\author{
Author(s): \\ N. Korkmaz'1 - M. Gündüz ${ }^{1}-$ Ş. Aşık² \\ Affiliation: \\ IInternational Agricultural Research and Training Centre, Camikebir Mah., Çavuşköyyolu Sok., No:9, 35660 İzmir, Turkey \\ ${ }^{2}$ Ege University Faculty of Agriculture Dept. of Farm Structures and Irrigation, 35100 Izmir-TURKEY \\ Email address: \\ nil_korkmaz@yahoo.com,gunduz.mehmet@gthb.gov.tr, serafettinasik@gmail.com
}

\begin{abstract}
The aim of the study was to determine the temporal and spatial variations in the level and salinity of groundwater. In 2011 and 2012 , in the rainy season, before the irrigation season, during the irrigation season and after the irrigation season the depth of groundwater was measured and at the same time groundwater samples were taken from each well. According to the results obtained, groundwater salinity was high in the years of the study, and its level was high in the rainy period and the irrigation period, but low before irrigation and after the irrigation period.
\end{abstract}

\section{Keywords}

ground water level, ground water salinity, spatial, temporal, Gediz

\section{Introduction}

It is a prerequisite of sustainable irrigated agriculture that irrigation should be done in such a way as to be effective and productive without damaging the environment. The most important role in meeting the world's need for food is played by areas of irrigated agriculture. It is a prerequisite of sustainable irrigated agriculture that it should be done in such a way as to be effective and productive without damaging the environment. Agricultural irrigation, especially when it is done with unsuitable techniques and in unsuitable amounts, can cause problems of salinity and alkalinity related to rising groundwater levels, especially in areas with topographic insufficiencies. Saline groundwater causes a reduction in the uptake of water from the soil by roots because of an increase of osmotic pressure in soil solutes, giving rise to a decrease in crop yield and quality. Soil productivity is affected by soil physical properties that play a crucial role in planning drainage systems. Improper planning of drainage systems can create high water table problems, and in turn, an unsuitable environment for plant growth. Therefore, drainage systems should be well planned and monitored regularly. It is labor-intensive and time-consuming to determine the spatial and temporal changes in drainage parameters such as ground water level, elevation, hydraulic gradient and salinity by conventional methods over large areas. Geographical information systems (GIS) and geostatistical analysis can be used to assess the spatial and temporal changes efficiently and rapidly [1].
Uninformed and uncontrolled irrigation in the Menemen Plain area, low efficiency of field irrigation practices and leaking from the canal network have caused the groundwater level to rise. In July, the month of the most intense irrigation, groundwater levels in the left bank irrigation area of the Menemen Plain do not fall below $101-150 \mathrm{~cm}$ in the $80.4 \%$ of the area close to the sea, and in $1.7 \%$ they do not fall below 51-100 cm [2]. Before management of the system was handed over to the irrigation association, average groundwater depths were approximately 186 $\mathrm{cm}$ and salinity was $2.65 \mathrm{dSm}^{-1}$, while after the handover, these figures were $148 \mathrm{~cm}$ and $3.14 \mathrm{dSm}-1$ [3]. The aim of this study is to determine temporal and spatial variation in the level and salinity of groundwater in the part of the Izmir-Menemen Plain left bank irrigation area which is close to the Aegean Sea with the use of the Geographical Information System and geostatistical methods.

\section{Material and method}

The Menemen Irrigation System is situated in the Gediz River basin in the west of Turkey, between $38^{\circ} 26^{\prime}-38^{\circ} 40^{\prime}$ north and $26^{\circ} 40^{\prime}-27^{\circ} 07^{\prime}$ east. The basin's alluvial base is divided into two by a narrowing at Emiralem, to the west of the city of Manisa. The part between this point and the sea is the Menemen plain. It lies at $10.3 \mathrm{~m}$ above sea level. At the site of the study, the soil has a fine loam texture, and is insufficiently to poorly drained and salty-alkaline, over the Gediz alluvial base. Cotton and grain are grown on most of the land [4]. The Menemen plain has a Mediterranean climate, with hot dry summers and cool wet winters. According to data collected over many years, total annual precipitation is $539.8 \mathrm{~mm}$. Average temperature is $16.90 \mathrm{C}$. In the two years of the study, 2011 and 2012, total precipitation was 812 $\mathrm{mm}$ and $624 \mathrm{~mm}$ respectively [5].

The catchment area of the Gediz basin is $17000 \mathrm{~km}^{2}$, and the

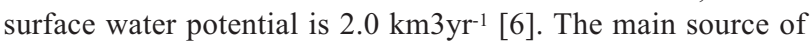
water of the Lower Gediz basin, including the Menemen Left Bank irrigation system, is the Demirkopru Dam, fed by the Gediz River, and the Marmara Lake. The Menemen Left Bank irrigation system consists of the left main canal which is connected to the Emiralem regulator, and six secondary canals. The system was constructed in 1944, and irrigates an area of 16585 ha. The area of the present study covers 2560 ha at the end of the Menemen Left Bank Irrigation area and is $7 \mathrm{~km}$ from the Aegean Sea. In this area, 67 groundwater observation wells were dug based on 
1/25000 digitised soil series maps. The wells were dug so that there was one for each 100 ha. Groundwater observation wells were located at 100, 300, 600 and $1000 \mathrm{~m}$ intervals in two of the 100 ha areas whose soil series showed little or great variation (Figure 1). The wells were generally opened to a depth of 3.80 $\mathrm{m}$, but at some points they were dug shallower due to pebbles. In the wells, PVC pipes were used with a diameter of $63 \mathrm{~mm}$ and with holes of $2 \mathrm{~mm}$ diameter spaced at intervals of $5 \mathrm{~cm}$. The locations of the observation wells were recorded with the Global Positioning Systems. In January, April, June, August and October of 2011 and 2012, groundwater (GW) levels were measured and water samples were taken from the same wells to measure electrical conductivity (EC). January and April represented the period affected by rain, June the pre-irrigation season, August the irrigation season, and October the post-irrigation season. EC (dSm-1) was established according to Standard Method 2510 B with the use of an electrical conductivity device [7].

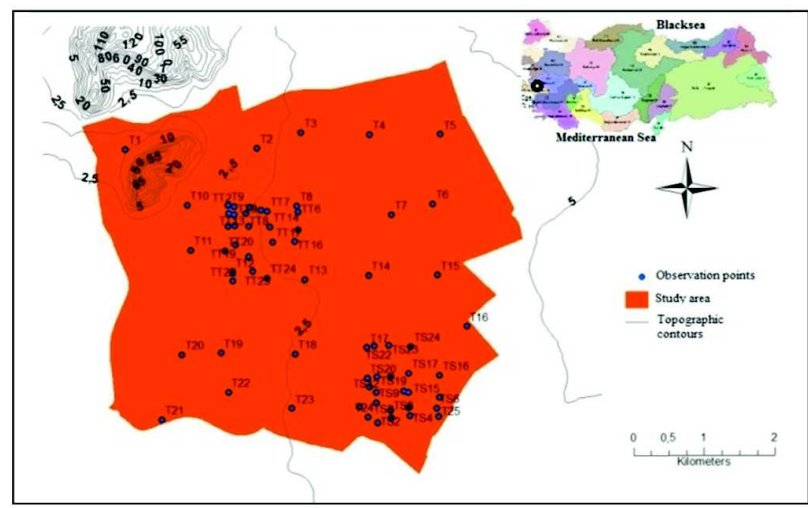

Figure 1. Location of study area with sampling points and topographic contours at $2.5 \mathrm{~m}$ intervals. Surface elevations are in meters above sea level.
The program ArcGIS 10.2 CBS was used for geostatistical modelling [8]. Using this program, groundwater level and EC maps were created for each period from the original data. Data were analyzed in three steps: (i) normality tests were conducted to test the hypothesis which assumes that each property is normally distributed (Kolmogorov-Smirnov); (ii) descriptive statistics including arithmetic mean, standard deviation and coefficient of variation, $\mathrm{CV}$, were calculated, and (iii) semivariogram analysis and complementary kriging interpolations were conducted for each variable. A proper transformation (log-transformation) was applied based on the result of the normality tests conducted using JMP 5.0.1 [9]. Geostatistical software (GS+7.0, [10]) was used to construct semivariograms and spatial structure analysis for variables. One of spherical, gaussion, exponential, and linear models was fitted to the experimental semivariograms by the least square fitting technique. Root mean squared error, coefficient of determination, and visual fitting were considered in selecting the models. Nugget variance expressed as the percent of total semivariance was used to judge the spatial dependency of variables. If the rate was equal or lower than $25 \%$, variables were considered as strongly dependent, between 25 and $75 \%$ moderately dependent, and greater than $75 \%$ weakly dependent [11].

\section{Results and discussion}

\section{Ground water level}

Tables 1-3 show the descriptive statistics, the semivariogram model and its parameters and the cross validation results for groundwater depth values measured in 2011 and 2012.

Table 1. Descriptive statistics for the ground water level by seasons $(\mathrm{cm})$ aStandard deviation, b Coefficient of variation

\begin{tabular}{|c|c|c|c|c|c|c|c|c|}
\hline Year & Seasons & Mean & Minimum & Maximum & $\mathrm{SD}^{\mathrm{a}}$ & $\mathrm{CV}^{\mathrm{b}}$ & Skewness & Kurtosis \\
\hline \multirow{5}{*}{2011} & January & $\underline{91}$ & $\underline{0}$ & 214 & 55 & $\underline{60.2}$ & 0.16 & -0.80 \\
\hline & April & 141 & 73 & 222 & 40 & 31.7 & 0.31 & -0.90 \\
\hline & June & 145 & 29 & 310 & 48 & 33.4 & 0.55 & 0.80 \\
\hline & August & 133 & 76 & 201 & 33 & $\underline{25.0}$ & -0.03 & -1.04 \\
\hline & October & $\underline{186}$ & 70 & $\underline{313}$ & 51 & 27.6 & 0.16 & 0.05 \\
\hline \multirow{5}{*}{2012} & January & 140 & $\underline{10}$ & 256 & 55 & $\underline{39.5}$ & -0.20 & -0.49 \\
\hline & April & 144 & 75 & 247 & 43 & 30.0 & 0.47 & -0.75 \\
\hline & June & 156 & 69 & 310 & 44 & 28.4 & 0.70 & 1.49 \\
\hline & August & $\underline{128}$ & 17 & 248 & 45 & 35.1 & -0.23 & -0.13 \\
\hline & October & 197 & 129 & $\underline{313}$ & 35 & 17.9 & 0.40 & 0.80 \\
\hline
\end{tabular}

In 2011, groundwater levels showed a variability of 0-313 cm, monthly averages $91-186 \mathrm{~cm}$, and coefficients of variation 25.0 $60.2 \%$. In 2012 these values were $10-313 \mathrm{~cm}, 128-197 \mathrm{~cm}$ and $17.9-39.5 \%$ respectively. Groundwater levels rose in the rainy period (January) and the irrigation period (August), and fell in the pre-irrigation (June) and post-irrigation (October) periods. This shows that rain and irrigation both cause the groundwater level to rise.

In all periods of the study years, groundwater levels showed a normal distribution, and the model which best fitted the data was the spherical isotropic semivariogram model. Range values varied in 2011 from 1100 to $2723 \mathrm{~m}$, and in 2012 from 1000 to $4570 \mathrm{~m}$. This model was also used in an evaluation in Turkey of groundwater levels of the Mustafakemalpaşa irrigation area and the Bafra Plain $[12,13]$. Degrees of spatial dependence varied between 13.6\% (June) and 50.0\% (August) in 2011 and 15.8\%
(June) and 42.4\% (August) in 2012. In April and June 2011 and April and October 2012, spatial dependence was classed as strong, and in the other months as moderate. Groundwater levels were classified as strong in spatial dependence classification in April and June 2011 and April and October 2012 and moderate for the other months.

The proportion of areas where the groundwater levels were above $90 \mathrm{~cm}$ was $40.5 \%$ in January $2011,1.4 \%$ and $1.5 \%$ in April and June 2011, 4.7\% in January 2012, and 5.2\% in August 2012. The proportion of areas where the two-year average was over $180 \mathrm{~cm}$ was found to be, in order of periods, 92.7, 88.6, $85.5,97.6$ and $60.1 \%$ (Figure 2). From the point of view of drainage and salinity, a groundwater depth of up to $2 \mathrm{~m}$ is seen as risky [14]. 
Table 2. Parameters of isotropic best fit semivariogram models of ground water level by seasons

\begin{tabular}{|c|c|c|c|c|c|c|c|c|c|}
\hline \multirow{2}{*}{ Year } & \multirow{2}{*}{ Seasons } & \multirow{2}{*}{ Nugget $\left(\mathrm{C}_{0}\right)$} & \multirow{2}{*}{$\begin{array}{c}\text { Sill } \\
\left(\mathrm{C}_{0}+\mathrm{C}\right)\end{array}$} & \multirow{2}{*}{$\begin{array}{l}\text { Range } \\
(\mathrm{m})\end{array}$} & \multirow{2}{*}{$\mathrm{C} / \mathrm{C}_{0}+\mathrm{C}$} & \multirow{2}{*}{$r^{2}$} & \multicolumn{2}{|c|}{ Spatial Dependency } & \multirow{2}{*}{ Model } \\
\hline & & & & & & & $\%$ & Class & \\
\hline \multirow{5}{*}{2011} & January & 1186 & 3380 & 2723 & 0.649 & 0.626 & 34.8 & moderate & Spherical \\
\hline & April & 378 & 1587 & 1819 & 0.762 & 0.608 & 23.8 & strong & Spherical \\
\hline & June & 389 & 2845 & 2668 & 0.863 & 0.927 & 13.6 & strong & Spherical \\
\hline & August & 512 & 1025 & 1702 & 0.500 & 0.637 & 50.0 & moderate & Spherical \\
\hline & October & 1000 & 2300 & 1100 & 0.565 & 0.642 & 43.5 & moderate & Spherical \\
\hline \multirow{5}{*}{2012} & January & 1050 & 3796 & 2690 & 0.723 & 0.820 & 27.7 & moderate & Spherical \\
\hline & April & 357 & 1991 & 2000 & 0.820 & 0.610 & 17.9 & strong & Spherical \\
\hline & June & 945 & 2258 & 4570 & 0.581 & 0.652 & 41.8 & moderate & Spherical \\
\hline & August & 865 & 2036 & $\overline{2060}$ & 0.575 & 0.589 & 42.4 & moderate & Spherical \\
\hline & October & 185 & 1172 & 1000 & 0.842 & 0.735 & 15.8 & strong & Spherical \\
\hline
\end{tabular}

Table 3. Results of cross-validation for ground water level

\begin{tabular}{|c|l|c|c|c|c|c|}
\hline Year & Seasons & ME & RMS & MS & RMSS & ASE \\
\hline \multirow{5}{*}{2011} & January & -0.803 & 40.0 & -0.0099 & 0.89 & 43.4 \\
\cline { 2 - 7 } & April & -0.498 & 29.7 & -0.0088 & 0.91 & 29.9 \\
\cline { 2 - 7 } & June & -0.436 & 33.5 & -0.0033 & 0.99 & 31.9 \\
\cline { 2 - 7 } & August & 0.154 & 29.1 & 0.0029 & 1.05 & 27.6 \\
\cline { 2 - 7 } & October & 0.417 & 48.5 & 0.0045 & 1.08 & 47.4 \\
\hline \multirow{4}{*}{2012} & January & -0.091 & 46.8 & 0.0003 & 1.05 & 42.9 \\
\cline { 2 - 7 } & April & -0.420 & 29.2 & -0.0085 & 0.90 & 30.4 \\
\cline { 2 - 7 } & June & -0.210 & 42.4 & -0.0018 & 1.10 & 37.3 \\
\cline { 2 - 7 } & August & -0.198 & 35.3 & -0.0023 & 0.92 & 36.7 \\
\cline { 2 - 7 } & October & 0.907 & 27.7 & 0.0181 & 1.00 & 26.7 \\
\hline
\end{tabular}

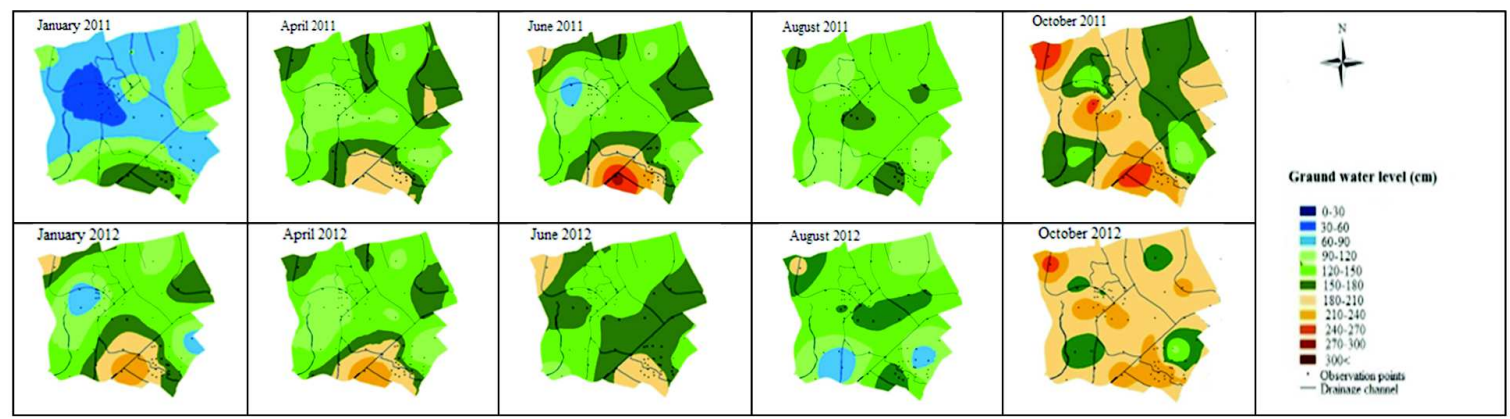

Figure 2. Spatial and temporal variation in groundwater levels for 2011 and 2012

\section{Ground water salinity}

Tables 4-6 show the descriptive statistics, the semivariogram model and its parameters and the cross validation results for groundwater EC values measured in 2011 and 2012.

Because groundwater salinity values showed log-normal distribution, transformation was applied before calculating the semivariogram. EC values showed consistency with the isotropic characteristic and the spherical semivariogram model. Range values varied between 3345 and $3790 \mathrm{~m}$ in 2011, and 2388 and $3049 \mathrm{~m}$ in 2012. Degrees of spatial dependence varied between $15.5 \%$ (January) and $45.9 \%$ (August) in 2011, and 21.5\% (August) and 41.8\% (October) in 2012. January 2011 and August 2012 were classed as strong regarding spatial dependence, and the other months as moderate.

Table 4. Descriptive statistics for the ground water salinity by seasons, $\left(\mathrm{dSm}^{-1}\right)$ ${ }^{1}$ Standard deviation, ${ }^{2}$ Coefficient of variation

\begin{tabular}{|c|l|c|c|c|c|c|c|c|}
\hline Year & Seasons & Mean & Minimum & Maximum & \multicolumn{1}{|c|}{ S.D. } & C.V. $^{2}$ & Skewness & Kurtosis \\
\hline \multirow{4}{*}{2011} & January & 7.58 & 0.78 & 33.72 & 7.5 & 98.8 & 1.76 & 2.85 \\
\cline { 2 - 9 } & April & 6.66 & 0.54 & 43.83 & 7.6 & 114.7 & 2.85 & 9.61 \\
\cline { 2 - 9 } & June & 7.69 & 1.06 & 38.25 & 7.7 & 101.9 & 1.87 & 3.39 \\
\cline { 2 - 9 } & August & 7.24 & 0.73 & 29.09 & 7.0 & 97.0 & 1.63 & 2.09 \\
\cline { 2 - 9 } & October & 7.58 & 1.06 & 30.83 & 7.9 & 103.9 & 1.58 & 1.54 \\
\hline \multirow{4}{*}{2012} & January & 6.89 & 0.72 & 58.18 & 8.6 & 125.2 & 3.71 & 18.20 \\
\cline { 2 - 9 } & April & 7.01 & 0.64 & 29.60 & 6.8 & 97.1 & 1.62 & 1.96 \\
\cline { 2 - 9 } & June & 6.90 & 0.76 & 24.46 & 6.7 & 96.7 & 1.40 & 0.77 \\
\cline { 2 - 9 } & August & 7.47 & 0.64 & 46.36 & 8.5 & 114.3 & 2.40 & 6.67 \\
\cline { 2 - 9 } & October & 7.00 & 0.90 & 42.45 & 8.1 & 115.7 & 2.45 & 6.66 \\
\hline
\end{tabular}

Nowhere in the study area was groundwater salinity found to be in the low or moderate classes. In terms of groundwater EC content classification, it was found that in 2011, proportional field quantities varied between $2.4 \%$ (August) and 9.0\% (April) in class 
III, between 3.7\% (August) and 6.5\% (October) in class IV, and between $84.3 \%$ (October) and $94.8 \%$ (August) in class V. The equivalent values for 2012 were $2.0 \%$ (October) - 5.6\% (August), $3.8 \%$ (April) - $11.2 \%$ (August) and 83.2\% (August) - $94.4 \%$ (June). It can be seen that no water of class I and II salinity was found in the study area, but that class V water was widespread ( $>80 \%)$. Areas with class III and IV salinity were generally in the south-east of the area. Spatial distribution of groundwater salinity was similar in the two years of the study, with no great differences between the years (Figure 3). In similar studies carried out in Turkey, it was found that groundwater salinity on the Lower Seyhan Plain was 28.8, 18.4 and $24.9 \mathrm{dSm}^{-1}$ in May, July and September 2006 respectively [15], and greater than $2 \mathrm{dSm}-1$ on only $5-7 \%$ of the area in Tokat-Kazova [16], in the right bank irrigation area of the Bafra Plain, which has a sea water entry, it varied between 1.36 and $11.9 \mathrm{dSm}^{-1}$, with an average of $4.18 \mathrm{dSm}^{-1}$ [17].

Table 5. Parameters of isotropic best fit semivariogram models of ground water salinity by seasons

\begin{tabular}{|c|c|c|c|c|c|c|c|c|c|}
\hline \multirow{2}{*}{ Year } & \multirow{2}{*}{ Seasons } & \multirow{2}{*}{ Nugget $\left(\mathrm{C}_{0}\right)$} & \multirow{2}{*}{$\begin{array}{c}\text { Sill } \\
\left(\mathrm{C}_{0}+\mathrm{C}\right)\end{array}$} & \multirow{2}{*}{$\begin{array}{c}\text { Range } \\
(\mathrm{m})\end{array}$} & \multirow{2}{*}{$\begin{array}{c}\mathrm{C} / \mathrm{C}_{0}+ \\
\mathrm{C}\end{array}$} & \multirow{2}{*}{$r^{2}$} & \multicolumn{2}{|c|}{ Spatial Dependency } & \multirow{2}{*}{ Model } \\
\hline & & & & & & & $\%$ & Class & \\
\hline \multirow{5}{*}{2011} & January & 0.168 & 1.086 & 3410 & 0.845 & 0.624 & 15.5 & strong & Spherical \\
\hline & April & 0.473 & 1.278 & $\underline{3790}$ & 0.805 & 0.852 & 37.0 & moderate & Spherical \\
\hline & June & 0.360 & 1.049 & 3554 & 0.689 & 0.886 & 34.3 & moderate & Spherical \\
\hline & August & 0.477 & 1.040 & 3680 & 0.541 & 0.897 & 45.9 & moderate & Spherical \\
\hline & October & 0.344 & 1.101 & $\underline{3345}$ & 0.688 & 0.700 & 31.2 & moderate & Spherical \\
\hline \multirow{5}{*}{2012} & January & 0.406 & 1.009 & 3018 & 0.598 & 0.804 & 40.2 & moderate & Spherical \\
\hline & April & 0.366 & 0.938 & 2538 & 0.610 & 0.824 & 39.0 & moderate & Spherical \\
\hline & June & 0.393 & 0.977 & 2948 & 0.598 & 0.829 & 40.2 & moderate & Spherical \\
\hline & August & 0.247 & 1.147 & $\underline{2388}$ & 0.785 & 0.625 & 21.56 & strong & Spherical \\
\hline & October & 0.442 & 1.057 & $\underline{3049}$ & 0.581 & 0.614 & 41.8 & moderate & Spherical \\
\hline
\end{tabular}

Table 6. Results of cross-validation for ground water salinity

\begin{tabular}{|c|l|c|c|c|c|c|}
\hline Year & \multicolumn{1}{|c|}{ Seasons } & ME & RMS & MS & RMSS & ASE \\
\hline \multirow{5}{*}{2011} & January & -0.011 & 6.71 & -0.118 & 1.24 & 6.05 \\
\cline { 2 - 7 } & April & 0.184 & 7.15 & 0.009 & 0.93 & 7.63 \\
\cline { 2 - 7 } & June & -0.230 & 7.49 & -0.118 & 1.22 & 6.99 \\
\cline { 2 - 7 } & August & 0.055 & 6.63 & -0.048 & 0.94 & 7.69 \\
\cline { 2 - 7 } & October & -0.136 & 7.01 & -0.084 & 1.03 & 7.36 \\
\hline \multirow{5}{*}{2012} & January & -0.017 & 8.10 & -0.060 & 1.07 & 7.24 \\
\cline { 2 - 7 } & April & 0.020 & 6.65 & -0.089 & 1.11 & 7.20 \\
\cline { 2 - 7 } & June & -0.009 & 6.25 & -0.065 & 1.04 & 6.94 \\
\cline { 2 - 7 } & August & -0.144 & 7.83 & -0.121 & 1.19 & 7.68 \\
\cline { 2 - 7 } & October & -0.162 & 6.97 & -0.003 & 0.85 & 7.35 \\
\hline
\end{tabular}

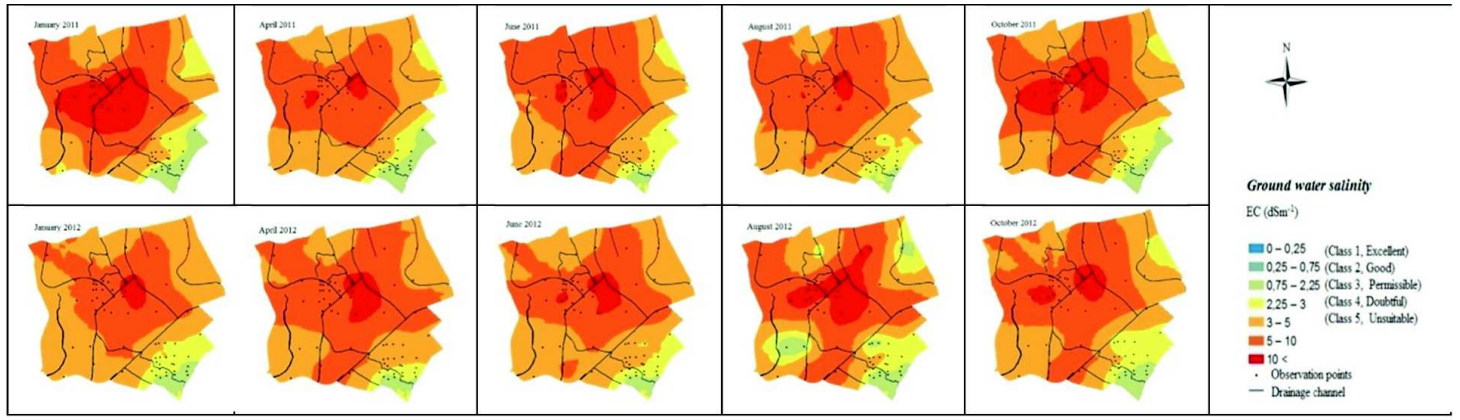

Figure 3. Spatial and temporal variation in EC of groundwater in 2011 and 2012

\section{Conclusion}

Spatial dependence in groundwater levels before and after the irrigation season was strong; in groundwater salinity values it was generally moderate. Geostatistical range values for ground water level were $1000 \mathrm{~m}$ and $2350 \mathrm{~m}$ for groundwater salinity, which, when evaluated together, must be taken as $1000 \mathrm{~m}$. The nugget effects of ground water level and ground water salinity were generally high. Sea effects and drainage differences were found in the study area. Groundwater levels rose in the rainy (January) and irrigation (August) periods, and fell in the preirrigation (June) and post-irrigation (October) periods. During the irrigation season, groundwater levels of $90-150 \mathrm{~cm}$ were found in $80 \%$ of the area. After the irrigation season, groundwater levels in $70 \%$ of the area fell to below $180 \mathrm{~cm}$. Groundwater salinity was greater than $3.00 \mathrm{dSm}^{-1}$ in $90 \%$ of the study area. Furrow irrigation was practiced in the study area. Collecting water charges by land area irrigated rather than by water volume causes a fall in water application ratio of $50-60 \%$. The mistaken practices of farmers in soil and water management cause the groundwater to rise and its salinity to increase. The performance of the existing drainage system in the study area in face of the high level and salinity of the groundwater should be evaluated, effective work should be carried out, and the 
practice of blocking drainage canals in order to collect water for use in irrigation should be stopped.

\section{References}

[1.] Cetin M., Diker K.: 2003. Assessing drainage problem areas by GIS: A case study in the eastern Mediterranean region of Turkey. Irrig. And Drain. Volume 52, pp. 343-353.

[2.] Çamoğlu G., Ölgen K., Karataş B. S. ve Aşik S. 2006. Menemen sulama sisteminde taban suyunun zamana ve mekana göre değişiminin değerlendirilmesi: Maltepe ana kanalı örneği, 4. Coğrafi Bilgi Sistemleri Bilişim Günleri, Fatih Üniversitesi. İstanbul.

[3.] Kıymaz S.: 2006. Gediz Havzası örneğinde sulama birliklerinin sorunları ve çözüm yolları, (Doktora Tezi), Cukurova Üniversitesi Fen Bilimleri Enstitüsü, Tarımsal Yapılar ve Sulama Bölümü, Adana.

[4.] Topraksu.: 1971. Menemen Ovası temel toprak etüdü, TOPRAKSU Genel Müdürlüğ̈ Toprak ve Etüd Haritalama Dairesi Raporları, Seri No: 24. Ankara.

[5.] Utaem.: 2014. Uluslararası Tarımsal Araştırma ve Eğitim Merkezi Müdürlüğü Menemen hidrometeorolojik rasat verileri, İzmir.

[6.] Baran T., Durnabaş İ., Özış Ü., ve Gül A.: 1999. Ege Bölgesinin yerüstü su potansiyeli, İzmir Su Kongresi, 4-5 Haziran 1999, İzmir, pp.57- 73

[7.] Apha-Awwa-Wpef.: 1998. Standard methods for the examination of water and wastewater, 20th edition, American Public Healty Association, Washington D.C.

[8.] Esri.: 2014. Using ArcGIS geostatistical analyst. environmental systems research institute, Redlands, CA, USA, $300 \mathrm{pp}$.
[9.] SAS Institute.: 1989. JUMP 5.0.1. A Business Unit Of SAS Copyright, $1989-2002$.

[10.] Robertson G. P.: 2000. GS+ : Geostatistics for the environmental sciences. Gamma Design Software.

[11.] Camberdella C. A., Moormann T. B., Novak J. M., Parkın T. B., Karlen D. L., Turco R. F., Konopka A. E.: 1994. Field-Scale Variability Soil Properties in Central Lowa Soils, Soil Sci. So. Am. J. Vol 58, pp.1501-1511.

[12.] Gündoğdu K. S.: 2004. Sulama proje alanlarındaki taban suyu derinliğinin jeoistetistiksel yöntemlerle değerlendirilmesi, Uludağ Üniversitesi Ziraat Fakültesi Dergisi, 18(2):85-95. Bursa. [13.] Cemek B., Demir Y., Erşahin S., Aslan H., Güler M.: 2006. Spatial variability of groundwater depth, soil salinity in irrigated of Bafra Plain in Northhern Turkey, International Symposium on Water and Land Management for Sustainable Irrigated Agriculture, Adana-Turkey.

[14.] Shegena Z.: 2012. Mapping of soil salinity in sego irrigation farm, southern Ethiopia using geospatial tools, Master of Science.

[15.] Çetin, M., Kırda, C., Efe, H. ve S. Topçu (2008), düşük kaliteli suların sulamada kullanılmasının neden olabileceği olası tuzluluk sorununun coğrafi bilgi sistemi ortamında irdelenmesi, TMMOB 2. Su Politikaları Kong, Volume 2, pp. 471-481, Ankara.

[16.] Akbaş F., Ünlükara A., Kurunç A., İpek U., Yıldız H.: 2008. Tokat-Kazova'da taban suyu gözlemlerinin CBS yöntemleriyle yapılması ve yorumlanması, Sulama ve Tuzlanma Konf., 12-13 Haziran, Şanlıurfa.

[17.] Arslan H., Cemek B., Demir Y., ve Yıldırım D.: 2011. Deniz suyu girişiminin belirlenmesinde çevresel izotopların kullanılması, Tarım Bil. Arş. Der.. Volume 4 (2), pp. 59-64. 